\title{
DELAVNICE JANES EKSPRES ZA PROMOCIJO KORPUSNIH IN SPLETNIH VIROV ZA SLOVENŠČINO
}

\author{
Jaka ČIBEJ \\ Filozofska fakulteta Univerze v Ljubljani
}

Čibej, J. (2015): Delavnice JANES Ekspres za promocijo korpusnih in spletnih virov za slovenščino. Slovenščina 2.o, 3 (2): 63-66.

URL: http://www.trojina.org/slovenscina2.o/arhiv/2015/2/Slo2.o_2015_2_o5.pdf.

\section{UVOD}

Novembra in decembra 2015 so Filozofska fakulteta Univerze v Ljubljani, slovenska raziskovalna infrastruktura za jezikovne vire in tehnologije CLARIN.SI ter regionalna iniciativa za jezikovne podatke ReLDI organizirale dogodek JANES Ekspres, ki ga je v okviru razpisa za promocijo slovenske znanosti $\mathrm{v}$ tujini sofinancirala Javna agencija za raziskovalno dejavnost Republike Slovenije (ARRS). Cilj projekta je bil raziskovalcem in študentom v Sloveniji, na Hrvaškem in $\mathrm{v}$ Srbiji s predavanji in delavnicami predstaviti obstoječe korpusne ter spletne vire za slovenščino in gradnjo, označevanje ter analizo korpusa spletne slovenščine JANES, ki nastaja v okviru temeljnega raziskovalnega projekta JANES.

\section{DELAVNICE V LJUBLJANI}

Najprej je 13. in 14. novembra na Institutu »Jožef Stefan« v Ljubljani potekala dvodnevna delavnica na temo označevanja korpusov z orodjem WebAnno. Petkov del delavnice je vodila Kaja Dobrovoljc (Zavod Trojina), ki je predstavila uporabnost in funkcionalnost orodja WebAnno. V sobotnem delu so Tomaž Erjavec (IJS), Jaka Čibej (FF UL) in Darja Fišer (FF UL) predstavili tehnične in jezikoslovne smernice za označevanje nestandardnih jezikovnih prvin $\mathrm{v}$ slovenskih tvitih. Dvodnevne delavnice se je udeležilo skupno 21 predavateljev, raziskovalcev in študentov humanistike in družboslovja iz vse Slovenije. 


\section{DELAVNICE V ZAGREBU}

4. decembra 2015 so predavanja in delavnice potekali na Filozofski fakulteti Univerze v Zagrebu. V dopoldanskih urah je Jaka Čibej za 72 udeležencev izvedel predavanje z naslovom »Jezikovni viri in orodja za slovenščino « ter na primerih predstavil rabo nekaterih slovenskih spletnih virov in orodij (npr. portal Fran, korpus Gigafida in oblikoslovni leksikon Sloleks), ki bodo študentom slovenistike koristili pri učenju in raziskovanju slovenščine. V popoldanskem času sta Tomaž Erjavec in Nikola Ljubešić (FF UZ in IJS) 19 doktorskim študentom, raziskovalcem in predavateljem jezikoslovja na delavnici približala tehnične in jezikoslovne smernice za označevanje nestandardnih jezikovnih prvin $\mathrm{v}$ hrvaški računalniško posredovani komunikaciji, Darja Fišer pa je s predavanjem predstavila orodje WebAnno.

\section{DELAVNICE V BEOGRADU}

Enak program, ki je bil prilagojen za srbščino, je bil izveden tudi 10. decembra 2015 na Filološki fakulteti Univerze v Beogradu. V dopoldanskem terminu je Jaka Čibej jezikovne vire za slovenščino predstavil skupno 35 študentom slovenistike, popoldne sta Tomaž Erjavec in Maja Miličević (FF UB) vodila delavnico o označevanju, Darja Fišer pa je predstavila orodje WebAnno še 34 doktorskim študentom, raziskovalcem in predavateljem jezikoslovja.

\section{ODZIVI IN REZULTATI}

Dogodek JANES Ekspres je bil izjemno uspešen tako v smislu obiska kot odziva skupno 192 udeležencev $\mathrm{v}$ treh različnih državah. Temeljni nacionalni raziskovalni projekt JANES in drugi sorodni projekti so bili predstavljeni široki študentski, raziskovalni in pedagoški javnosti, s čimer je bil dosežen velik krog neposrednih uporabnikov projektnih rezultatov.

Dogodek je izpolnil tri cilje. Študentje slovenistike so se seznanili s spletnimi viri za učenje in raziskovanje slovenščine, ki so bili razviti $\mathrm{v}$ okviru 
mednarodnih in nacionalnih raziskovalnih projektov. Pridobili so znanja in veščine za kompetentno samostojno rabo teh virov in orodij, zato je mogoče pričakovati, da bodo viri odslej uporabljani v mnogo širšem okviru. Doktorski študentje, raziskovalci in predavatelji so se seznanili s prosto dostopnim spletnim orodjem za označevanje jezikovnih podatkov WebAnno, kar bo odslej tudi sicer slabše podprtim jezikom omogočalo izdelavo označenih podatkovnih množic za jezikoslovne raziskave. S predstavitvijo smernic za označevanje nestandardnih jezikovnih prvin v računalniško posredovani komunikaciji pa je bilo vzpostavljeno tudi regionalno sodelovanje pri označevanju jezikovnih podatkov in pri računalniško podprtih jezikoslovnih raziskavah - sodelovanje, ki je bilo še dodatno potrjeno z dogovorom o skupnih načelih označevanja podatkov v regiji in skupnem razvoju jezikovno neodvisnih modelov in orodij za raziskovanje južnoslovanskih jezikov.

Vsa gradiva $\mathrm{z}$ dogodka so prosto dostopna na spletni strani dogodka JANES Ekspres. 


\section{JANES EKSPRES WORKSHOPS FOR PROMOTING CORPORA AND LANGUAGE RESOURCES FOR SLOVENE}

To delo je ponujeno pod licenco Creative Commons: Priznanje avtorstvaDeljenje pod enakimi pogoji 4.o Slovenija.

This work is licensed under the Creative Commons Attribution ShareAlike 4.o License Slovenia.

http://creativecommons.org/licenses/by/4.0/

(c) (i) (2) 